\title{
Military Commissions and the Paradigm of Prevention
}

David Cole

Georgetown University Law Center, cole@law.georgetown.edu

Georgetown Public Law and Legal Theory Research Paper No. 12-154

This paper can be downloaded free of charge from:

https://scholarship.law.georgetown.edu/facpub/1110

http://ssrn.com/abstract=2165507

David D. Cole, Military Commissions and the Paradigm of Prevention, in GUANTANAMO AND BEYOND: EXCEPTIONAL COURTS AND MILITARY COMMISSIONS IN AND POLICY PERSPECTIVES (Oren Gross and Fionnuala Ni Aolain, eds., Cambridge: Cambridge Univ. Press forthcoming 2013)

This open-access article is brought to you by the Georgetown Law Library. Posted with permission of the author. Follow this and additional works at: https://scholarship.law.georgetown.edu/facpub

Part of the Constitutional Law Commons, Criminal Law Commons, Criminal Procedure Commons, Human Rights Law Commons, International Law Commons, and the National Security Law Commons 


\title{
MILITARY COMMISSIONS AND THE PARADIGM OF PREVENTION
}

\author{
By David Cole
}

\section{INTRODUCTION}

Why military commissions? That is the central question posed by President George W. Bush's decision to create the commissions in the first place, by Congress's decision to authorize them twice in statutes enacted in 2006 and 2009, and by President Barack Obama's decision to continue their use under his administration, notwithstanding his criticisms of them as a candidate. There is, no doubt, historical precedent for military commissions - but for the most part, that historical precedent involved materially different situations, in which military commissions were a matter of necessity, not discretion. Military commissions were employed, for example, where the military had ousted the existing government, and had to provide some venue for the enforcement of law as an occupying force. Moreover, their procedures have generally conformed to those of courts-martial. In the current circumstances, by contrast, there seems to be little or no necessity for military commissions. Most of the conduct charged and tried as war crimes in military commissions could be charged and tried in civilian criminal courts, under ordinary terrorism laws. And if it is thought that a military court is particularly appropriate for the trial of war crimes, the preexisting and established system of courtsmartial could have been employed.

Both the civilian criminal court and the court-martial are preferable venues for many reasons. They both have established track records. The United States has a robust civilian criminal justice system, in which many individuals have been tried successfully for terrorist crimes, both before and after September 11, 2001. And the United States has an equally strong court-martial system, with rules of evidence that largely track those of civilian criminal courts, and in which thousands of criminal trials have been successfully conducted. The rules governing civilian criminal proceedings and courts-martial are clear, well-settled, and have been subjected to and survived repeated constitutional testing. The judges are experienced in conducting trials. There is substantial precedent to guide their decisions, which decreases the likelihood of erroneous or arbitrary decision making, and in turn reduces the likelihood of long and costly appeals and retrials.

Perhaps most significantly, civilian criminal trials and courts-martial enjoy the imprimatur of legitimacy. American criminal procedure has its flaws, to be sure, but apart from its reliance on the death penalty, its criminal trial practices are not generally subject to criticism for the denial of basic human rights. ${ }^{1}$ Both the civilian justice system and the court-martial proceedings afford defendants the right to notice of the charges, the right to confront and rebut the evidence against them, the assistance of counsel, the right to a trial by a jury of one's peers, the privilege against compelled self-incrimination, the right to independent appellate review, and a panoply of other rights. Moreover, at least as a formal matter, the rules apply equally to all defendants. A foreign national being tried for a criminal offense in a civilian court or a court-martial has all the same trial rights that a US citizen does. As a result, when an individual is convicted in either a civilian criminal 
court or a court-martial, there is a presumption that his conviction was warranted. Injustices occur, of course; but the burden is on the individual convicted to demonstrate that in his case injustice was done.

Military commissions, by contrast, are largely untested; the few military commission proceedings that have been conducted at Guantánamo thus far have been rife with errors, misfires, and embarrassments. Military commissions are discriminatory on their face, as they apply only to foreign nationals, not U.S. citizens accused of the very same conduct. And in large part because the Bush administration's initial version of military commissions was patently invalid, their procedures are widely perceived as illegitimate. The military commissions have already gone through at least three separate iterations, and every attempt to proceed has been beset by countless problems. The initial post-9/11 commissions were created by a summary presidential order, supplemented by barely more detailed military orders. They allowed the introduction of testimony obtained through torture, permitted defendants to be tried effectively in absentia, and contemplated no judicial review. The president supervised the prosecution, the judges, the defense, and was the final stage of appeal. When the Supreme Court ruled in 2006 that the original commissions violated the laws of war and the Uniform Code of Military Justice, in Hamdan v. Rumsfeld, ${ }^{2}$ Congress responded with the 2006 Military Commissions Act ("2006 Act"). That act did relatively little to correct the procedural deficiencies in the military commissions, still permitted the introduction of coerced testimony, and treated conduct as "war crimes" that had never before been so recognized, including "material support" to terrorism and "conspiracy."

The few attempts to pursue military charges in military commissions under the 2006 Act were beleaguered by legal problems. Several military lawyers involved in the process resigned because of ethical concerns regarding interference with the process, the use of tortured evidence, and attempts to conceal exculpatory evidence from defense counsel. Practically the only convictions obtained were through guilty pleas that effectively granted defendants a short fixed term and release from Guantánamo, a better deal than the indefinite detention they otherwise faced as "enemy combatants." None of those tried were central figures; more often than not, they were drivers or foot soldiers. When President Obama took office, Congress enacted the Military Commissions Act of 2009 ("2009 Act"), which improved the procedures substantially - but still fell short of providing the guarantees available in military courts-martial, continued to apply exclusively to foreign nationals, and still authorized charges for conduct that the rest of the world had never viewed as a war crime. As of this writing, the Obama administration has re-started military commission proceedings against Khalid Sheikh Mohammed, the alleged mastermind of the $9 / 11$ attacks. After an aborted military commission proceeding brought against KSM by the Bush administration, the Justice Department under Obama initially decided to try Mohammed in a civilian criminal court in New York City. When political opposition mounted and Congress tied its hands by barring the expenditure of funds to bring Guantánamo detainees to the United States, even for a criminal trial, the Obama administration indicted KSM again before a military commission. Those proceedings have only begun, but if recent history is any indication, the new proceedings 
will again be tied up in knotty problems, for which there will be little if any precedent to guide the military judges who preside.

Why invite such trouble? If Guantánamo detainees have committed terrorist offenses, they can be tried in civilian criminal courts. If the president believes that some should be prosecuted for war crimes in a military venue, courts-martial could be employed for that task. In his May 2009 speech on national security at the National Archives, President Obama expressed a strong preference for civilian criminal trials, stating that "wherever feasible," those held at Guantánamo would be tried in civilian criminal court. ${ }^{4}$ But he retained the option of trials in military commissions, explaining:

Military commissions have a history in the United States dating back to George Washington and the Revolutionary War. They are an appropriate venue for trying detainees for violations of the laws of war. They allow for the protection of sensitive sources and methods of intelligence-gathering; they allow for the safety and security of participants; and for the presentation of evidence gathered from the battlefield that cannot always be effectively presented in federal courts. ${ }^{5}$

Do these justifications warrant the use of military commissions? In this essay, I maintain that they do not. In the end, the impetus behind the military commissions is the hope - in my view, unsupported - that the commissions may permit easier convictions of individuals, and may allow prosecutors to avoid confronting the consequences of the United States' systemic reliance on torture and cruel, inhuman, and degrading tactics in its interrogations of detainees. In this respect, the commissions are best understood not as a legitimate forum for trying war crimes, but as an avenue for short-circuiting legal processes that might hold us accountable for our wrongs.

The military commissions are a by-product of the "paradigm of prevention," a term coined by then-Attorney General John Ashcroft for the post-9/11 emphasis on aggressively preventing future terrorism, rather than responding to crime after the fact. That approach stressed early intervention and aggressive gathering of intelligence about future threats, and therefore led government officials to sweep broadly, presume guilt without substantial evidence, detain innocents, and adopt "enhanced interrogation techniques" to coerce detainees into talking. Those choices, in turn, have greatly complicated and compromised the task of holding terrorists accountable, because such illegal shortcuts on investigatory rules taint any evidence obtained therefrom, and make it inadmissible in a criminal trial.

The military commissions reflect an ill-advised effort to avoid paying the price for the "paradigm of prevention." That goal is an illegitimate one, and will in the end leave the commissions - and any convictions obtained in them - fundamentally tainted. Absent a willingness both to reckon candidly with the United States' own past wrongs, and to proceed in the future under fundamentally fair trial procedures, the military commissions are likely to disserve our security interests and undermine our constitutional principles. 


\section{THE ASSERTED JUSTIFICATIONS FOR MILITARY COMMISSIONS}

President Obama offered four justifications for the use of military commissions: (1) they are an appropriate forum for trying war crimes; (2) they "allow for the protection of sensitive sources and methods of intelligence-gathering;" (3) they are more secure; and (4) their evidentiary rules are more tolerant, recognizing that evidence gathered from the battlefield cannot be expected to meet the requirements we impose in civilian criminal courts. These rationales are not frivolous, and may well justify military commissions in certain circumstances. But they do not suffice to justify the military commissions in the form they take under the 2009 Act and as they have been and are being employed by the military at Guantánamo.

Military commissions have been used to try individuals for war crimes, but they are generally restricted to situations of necessity, where other courts are unavailable. Thus, for example, the United States first employed military commissions during the Mexican War, in order to maintain order in occupied territory, where neither U.S. civilian courts nor courts-martial had jurisdiction. ${ }^{6}$ They were used during the Civil War with mixed results, sometimes properly employed to try war crimes subject to procedures equivalent to those provided in courts-martial, but other times used, it appeared, to ensure convictions. ${ }^{7}$ When President Lincoln sought to use a military commission to try a civilian accused of supporting the rebel forces, the Supreme Court held that he had overstepped his authority, and that civilians could not be tried in a military commission where the civilian courts were open and ready for business. ${ }^{8}$ Military commissions were used during the Philippines Insurrection of 1899-1902, but their procedures conformed to those in courts-martial, and they used the same rules of evidence used in civilian courts. ${ }^{9}$ Thus, military commissions are most legitimate when used as a matter of necessity, and without departing significantly from the procedural practices in other courts.

There are exceptions to this pattern, to be sure. The most prominent - and the most dubious - is the military commission that President Franklin D. Roosevelt created to try Nazi saboteurs who landed in the United States in a German U-boat, crossed the border wearing civilian clothes, and were planning to blow up munitions factories. The saboteurs could have been tried in civilian courts for their crimes, and civilian courts were certainly open for business. Roosevelt had them tried in a military commission, empowered to create its own rules, with an appeal only to him, because he feared that a civilian criminal trial would not lead to a sufficient penalty. But there is also evidence that the government did not want it known that the men were discovered only because one of the saboteurs chose to turn on his partner and revealed the conspiracy to the FBI. ${ }^{10}$ The trials were held behind closed doors in the Justice Department, and most of the saboteurs were sentenced to death. The Supreme Court took up an extraordinary habeas review of the tribunal while it was underway, affirmed the tribunal's jurisdiction in a summary order one week later, and did not write its decision justifying its result until after the defendants had been executed.

It is far from clear that military commissions are a matter of necessity for trials of most of those held at Guantánamo. In the case of Khalid Sheikh Mohammed, for 
example, the United States was fully prepared to try him and his coconspirators in a civilian criminal court in Manhattan; in fact, the Justice Department determined that a civilian criminal trial was the more appropriate forum. But if they can be tried in a civilian criminal court, it is not even clear that we should be able to resort to military commissions, because in that context, the commissions are evidently not a matter of necessity. Most war crimes are also a federal crime prosecutable in civilian criminal court. ${ }^{11}$ The most frequent charge thus far in the military commissions has been the provision of "material support" to terrorism. But federal criminal law also prohibits material support to terrorist groups, including Al Qaeda, as well as material support to terrorist acts. ${ }^{12}$ In some instances, these domestic laws may not have had a sufficient extraterritorial reach at the time Guantánamo detainees engaged in the conduct for which they might be charged. If their conduct was nonetheless a war crime, then a military forum might be the only venue in which they could be tried; but in that case, military courts-martial would be available. In many instances, in any event, individuals could be tried in civilian criminal court for violating federal laws. And if a detainee's conduct could be prosecuted in civilian criminal court, or even in a court-martial, the administration must point to some rationale other than the "appropriateness of military commissions for war crimes" to justify proceeding in a military commission.

The second rationale President Obama advanced - the need to protect sensitive sources and methods of intelligence-gathering - also provides little support for using military commissions. Federal civilian courts are well acquainted with classified information and maintaining secrecy where warranted. Under the Foreign Intelligence Surveillance Act, federal judges hear classified requests for orders authorizing wiretapping and searches for foreign intelligence and counterterrorism purposes. ${ }^{13}$ Under the Classified Information Procedures Act ("CIPA"), federal courts handle and assess classified information related to criminal trials. ${ }^{14}$ In the habeas corpus proceedings reviewing Guantánamo detentions that federal courts in the District of Columbia have been conducting, the federal courts routinely consider classified information, and attorneys for both sides have access to the information and may rely on it in their briefs, so long as they are filed under seal. Thus far, there have been no reports of mishaps or leaks. By contrast, virtually all of the military's secret intelligence assessments of Guantánamo detainees were disclosed to WikiLeaks, allegedly by a military intelligence operative, and then released by WikiLeaks and several news outlets to the general public. Thus, it is far from clear that the military process has any distinct advantage over civilian courts when it comes to keeping secrets.

If President Obama meant that trials in military commissions might permit individuals to be tried and convicted on evidence without disclosing its source, it is not clear that the military commission rules make that possible. The treatment of classified evidence in military commissions under the 2009 Act is closely modeled on the CIPA rules that govern civilian criminal trials, and those rules appear to provide no advantage to using military commissions. Moreover, any such shortcut would very likely deprive the defendant of the fundamental elements of a fair trial. If due process applies to the Guantánamo military commissions - and it is likely to, given the extension of habeas corpus there - the prosecution will not be able to conceal sources and methods of 
evidence gathering wherever access to those sources and methods is necessary to confront the evidence used against the defendant. As a matter of due process and fundamental fairness, defendants would presumably be entitled to know, for example, whether any evidence used against them was obtained from coerced testimony, or from a lead generated through coerced testimony. They would also presumably be entitled to know the identity of their accusers, because without that information one cannot meaningfully challenge the reliability of what has been said. Any trial in which such information was denied to the defense would very likely be viewed as illegitimate - and properly so. Thus, it is simply not evident that military commissions, if they are to be fair, will be able to protect sensitive sources and methods any more robustly than civilian criminal trials.

The third rationale President Obama offered for military commissions is that the proceedings can be made more secure for the participants, presumably because they can be held on a military base, far from a civilian population, and subject to the security measures the military can provide. It is certainly plausible that it would be easier to hold a secure trial at Guantánamo than in the heart of Manhattan, but the difference is really a geographic one and has nothing to do with the difference between a military and a civilian trial. A civilian trial at Guantánamo would be easier to make secure than a military trial in Manhattan. Congress could presumably authorize a federal civilian court to conduct trials at Guantánamo, just as a federal civilian court conducted certain legal proceedings in Berlin after the war. ${ }^{15}$

Fourth, President Obama reasoned that military commissions might admit and consider evidence gathered from the battlefield that could not satisfy the rigorous requirements that apply to evidence in a civilian criminal court. There may well be some situations in which this will prove a salient difference. But courts-martial have for years dealt with situations that arise on or near battlefields, and they apply largely the same evidentiary rules as civilian criminal trials. Moreover, many of the detainees at Guantánamo were not picked up on a battlefield at all, but were captured far from any battlefield, or were turned over by bounty hunters. For the vast number of detainees not captured on the field of battle, Obama's fourth rationale would be inapplicable, and the administration has offered no reason why the government should be permitted to avoid ordinary evidentiary requirements in such cases. Those requirements, after all, are designed only to ensure the accuracy and reliability of evidence; they were not created simply to impose meaningless obligations on government. Short-circuiting them comes at a cost to reliability - a cost that may arguably be warranted in some battlefield situations, but not otherwise.

Finally, and perhaps most importantly, the fact that military commissions are applicable only to foreign nationals accused of war crimes, and not to U.S. citizens accused of the same crimes, undermines all of the above arguments. If a military commission is appropriate to try foreign nationals for war crimes, why would it not be equally appropriate to try U.S. nationals? Concerns about sources and methods, the security of the proceedings, and the difficulties of evidence gathering on the battlefield are exactly the same whether the defendant is a U.S. citizen or a foreign national. Yet we 
have committed to trying U.S. citizens accused of war crimes in civilian criminal courts. John Walker Lindh, the so-called American Taliban, captured on the battlefield in Afghanistan, was tried in a civilian criminal court for "material support," not in a military commission. If the civilian criminal court system is sufficient for trying U.S. citizens, it is sufficient for trying foreign nationals as well. ${ }^{16}$

\section{MILITARY COMMISSIONS AS AN OUTGROWTH OF THE PREVENTIVE PARADIGM}

The poverty of the asserted justifications for military commissions suggests that what is really at stake is some other, unstated interest. Some advocates of using military commissions appear to be driven by an ideological commitment to military commissions as a fundamental feature of the "war paradigm." The view that the struggle with Al Qaeda is properly understood as a war, and that therefore civilian criminal law measures are inappropriate, no doubt motivates some of the commentators who insist on the use of military tribunals. But that is not President Obama's view, and does not reflect accurately President Bush's practice. Both Presidents Bush's and Obama's administrations have prosecuted Al Qaeda-related would-be terrorists in civilian criminal court; neither took the position that civilian criminal measures were inappropriate ab initio for terrorism cases, or for Al Qaeda terrorism cases. ${ }^{17}$

What seems a more likely motive for the persistence of military commissions is the hope that by employing such commissions, the United States might avoid paying the costs of its imprudent resort to illegal tactics in pursuing the "paradigm of prevention." In a meeting on September 12, 2001, at the White House, recounted by Bob Woodward in Bush at War, FBI Director Robert Mueller was briefing the National Security Council on the events of the day before, and stressing the need to investigate in a manner that did not taint the evidence. At that point, Woodward reports, Ashcroft interrupted: "Let's stop the discussion right here. The chief mission of U.S. law enforcement, he added, is to stop another attack and apprehend any accomplices or terrorists before they hit us again. If we can't bring them to trial, so be it." "18

In the days that followed, the Bush administration followed Ashcroft's advice, not Mueller's. But while it readily adopted Ashcroft's prescription for prevention, it was less willing to accept his "so be it" with regard to prosecution. The military commissions can be understood as an attempt to act preventively and "bring them to trial," to avoid the trade-off that Ashcroft suggested was necessary and warranted.

The Bush administration embraced wholeheartedly the "paradigm of prevention." In the first days, months, and years after $9 / 11$, it used a variety of mechanisms to detain individuals before they committed an act of terrorism. By definition, this meant sweeping broadly, because the government could not, of course, predict who would actually commit a terrorist act if left free. In the United States, Ashcroft oversaw an aggressive deployment of immigration law, the "material witness" statute, and pretextual 
prosecutions in the first two years after 9/11 that led to the detention of more than five thousand foreign nationals suspected, often on the slimmest of reeds, of possibly being involved in terrorism. ${ }^{19}$ Nearly all were Arab or Muslim men. Of the five thousand detained, none were actually charged and convicted of any act of terrorism. Most were held on immigration charges, often exceedingly technical. And many were held without any evidence that they actually posed any danger to the community, much less of terrorism.

Beyond our borders, the Bush administration followed a similar policy of sweeping detention. It brought 779 "terror suspects" to Guantánamo. The administration insisted initially that these detainees were the "worst of the worst," and claimed that they had been carefully screened. Yet by the time the Bush administration had left office it had released more than five hundred of them. It had little or no reliable evidence that many of these individuals were in fact dangerous, and when the Supreme Court ruled that the detainees were entitled to review the legality of their detentions in court, the Bush administration started releasing many of those it had once claimed were "the worst of the worst." The majority were not captured by U.S. forces, but were turned in by others, often to obtain bounties that were equivalent to a year's salary in Afghanistan. Secret military intelligence assessments of the risk posed by each detainee, disclosed by WikiLeaks in 2011, revealed that the military classified many as "high risk," but released them anyway, and that the assessments were often based on unreliable statements obtained through coercion, without any acknowledgment by the military that the statements might be unreliable. ${ }^{20}$

The administration's broad-brush preventive approach in turn placed tremendous pressure on using interrogation as an intelligence-gathering mechanism. Law enforcement and intelligence agents generally prefer not to detain suspects prematurely, because once one does so, the suspect and his accomplices know that the government is aware of their activities. Where one can instead maintain surveillance without imminent danger, it is far better, both from an intelligence perspective and from the standpoint of gathering admissible evidence to prosecute, as such surveillance is often more likely to provide a better understanding of the scope of the conspiracy or illegal scheme. If, in the name of prevention, suspects are detained prematurely and on scant information, then the only way to gather intelligence is by interrogation.

At the same time, if one sweeps broadly, many of those detained are likely to be innocent, and may well lack any information regarding true threats. If so, interrogation will often prove frustrating, as interrogators confront "suspects" who actually have nothing to tell them. Moreover, an ideologically driven opponent is likely to be less willing to share information than an ordinary criminal defendant, so it will be difficult to distinguish those genuine suspects who have information and are not sharing it from mistaken suspects who simply have nothing to share.

These circumstances quickly led the Bush administration to entertain the possibility of employing harsh interrogation tactics. In August 2002, the Justice Department, with the approval of President Bush and Vice President Cheney, authorized 
the CIA to use "enhanced interrogation tactics," including slamming suspects into walls, sleep deprivation of up to eleven days straight, painful stress positions, confinement in small boxes, and waterboarding, in order to obtain information from "high-value detainees" who had been "disappeared" into CIA secret prisons. A few months later, Defense Secretary Donald Rumsfeld authorized interrogators at Guantánamo to use similar, though somewhat less extreme, tactics. These tactics were used for over 100 days straight on one Guantánamo detainee, Mohammed al Qahtani, to such an extent that the military's own prosecutor, Susan Crawford, determined that she had to dismiss a war crimes case against him because al Qahtani had been tortured. After the officer in charge at Guantánamo visited Abu Ghraib, similar tactics "migrated" there. The administration also adopted a policy of "extraordinary rendition," in which suspects were kidnapped and delivered to security officials in countries like Syria, Egypt, and Jordan, to be interrogated using the very torture tactics that the United States State Department has long condemned in those countries.

The Bush administration justified all of these tactics in the name of preventing the next attack. There is no evidence that the tactics actually preempted any actual attacks. As noted above, none of the five thousand foreign nationals preventively detained in the United States was convicted of a terrorist offense. The CIA's own Inspector General, in a study of the "enhanced interrogation tactics," concluded that it identified no evidence that the coercive tactics obtained information that lawful interrogation could not have obtained, and indeed that in many instances it could not disentangle information obtained from legal and coercive tactics. President Bush and Vice President Cheney claimed repeatedly that the tactics had "saved lives," but never identified a single instance in which that claim could be verified. After a naval special operations team killed Osama bin Laden in May 2011, some of those who authorized torture argued that their tactics had led to the discovery of bin Laden's hiding place by helping to identify the courier that eventually led investigators to bin Laden, but the facts do not support their self-interested claim. Khalid Sheikh Mohammed and Abu Faraj al-Libi were subjected to enhanced interrogation tactics, but neither is reported to have identified the courier. In fact, both provided affirmatively misleading information regarding the courier after they were subjected to enhanced interrogation techniques. And neither provided any information at all about the courier in direct response to the enhanced interrogation techniques, but only long afterward, in response to ordinary questioning. ${ }^{21}$

Whether or not such tactics - illegal detentions, renditions, torture, and cruel, inhuman, and degrading treatment - resulted in useful information is at best debatable. It is indisputable, however, that because they are illegal, they taint any evidence obtained from their deployment. As a result, such information would plainly be inadmissible in a civilian criminal court - or a court-martial, where similar rules of exclusion apply. Moreover, even if the government attempts to make its case without relying affirmatively on any tainted evidence, defendants who have been subjected to such tactics are almost certain to seek to use it in their defense. It might support a claim that as a result of their mistreatment, they are no longer mentally competent to stand trial. The use of such tactics on a systemic basis calls into question virtually any evidence the government gathers subsequently, as much of it may be linked back, through some chain of leads or 
"mosaic," to the use of torture or coercive interrogation. Defense lawyers would be ineffective if they did not aggressively pursue discovery of potentially exculpatory evidence regarding these practices and their potential impact on any evidence the government sought to introduce.

As anyone with foresight would have predicted, the administration could not really accept the consequences of Ashcroft's "so be it" statement of bravado. There are substantial moral, political, and legal pressures to bring to justice those who have perpetrated acts of terrorism. The United States cannot responsibly leave unprosecuted those who attacked it on September 11 and killed three thousand innocent civilians. But how, for example, does the United States try Khalid Sheikh Mohammed after he has been disappeared into a secret prison for years, and waterboarded 183 times?

Military commissions were the Bush administration's answer. As initially formulated by the executive branch, the commissions would permit defendants to be tried on the basis of coerced testimony. When the Supreme Court declared President Bush's military commissions to be in violation of the Uniform Code of Military Justice and Common Article 3 of the Geneva Conventions, Congress enacted the Military Commissions Act of 2006. This act prohibited admission of tortured statements, but permitted statements coerced through mistreatment short of torture so long as a military judge deemed it "reliable." 23

In 2009, Congress again amended the rules governing military commissions, and tightened the rules for admissibility of an accused's statements. The 2009 Act prohibits categorically the introduction of any statement obtained through torture or cruel, inhuman, or degrading treatment. ${ }^{24}$ It generally requires that an accused's prior statements can be introduced only if deemed voluntary - which is what the Supreme Court has long ruled that due process requires in civilian criminal trials. ${ }^{25}$ But it still makes an exception, permitting even involuntary statements if the military judge finds that "the statement was made incident to lawful conduct during military operations at the point of capture or during closely related active combat engagement, and the interests of justice would best be served by admission of the statement." ${ }^{, 6}$ This exception appears to be narrow, and presumably would not apply to statements obtained at CIA "black sites" or at Guantánamo, as these would not meet the requirement that they be "at the point of capture or during closely related active combat engagement." Thus, while the commission rules were initially designed to permit the introduction of coerced testimony, thereby allowing the government to avoid paying the cost of its illegal interrogation tactics, under the current rules that particular loophole has largely been closed.

The military commissions, however, continue to seek to further the government's "preventive paradigm" in still another way - they permit prosecution for conduct that was in fact not a crime when it took place, and that is not a war crime at all. The 2009 Act, like the 2006 Act, makes it a crime, for example, to provide "material support or resources to an international terrorist organization engaged in hostilities against the United States." ${ }^{, 27}$ The international laws of war, however, have never recognized "material support" as a war crime. The statute also permits prosecution for "conspiracy" 
to engage in any other war crime, including "material support." In Hamdan, the Court's four-Justice plurality concluded that "conspiracy" was not a war crime under the laws of war. ${ }^{28}$ Justice Kennedy, the fifth vote, deemed it unnecessary to reach the issue. If these "crimes" are not recognized internationally by the laws of war, two issues arise: (1) may Congress, pursuant to its authority to define offenses against the law of nations, enact "war crimes" that in fact have no foundation in the laws of war; and (2) even if Congress has the power to expand the scope of "war crimes," if these acts were not recognized as war crimes by the laws of war, application of the 2009 Act to acts committed prior to its enactment constitutes ex post facto punishment.

The administration's interpretation and enforcement of other "war crimes" has also raised serious legal questions about its misuse of the law of war. David Glazier argues convincingly, for example, that the United States has effectively sought to make fighting for the other side a war crime, without more. ${ }^{29}$ Thus, in its prosecution of Omar Khadr, a young Canadian captured on the battlefield after shooting an American soldier, the government argued that Khadr had committed murder and attempted murder in violation of the laws of war by merely engaging in battle against the United States military on behalf of Al Qaeda. The United States' theory appears to be that since Al Qaeda does not have the privilege of belligerency, any fighting anyone engages in on its behalf, even when targeted at combatants, is a war crime. On this view, it is a war crime for Al Qaeda to fight, and the law of war would become a sword under which the United States can shoot to kill their combatants, but they can't shoot back at U.S. combatants. The government's approach, Glazier argues, "repudiates the functional equivalence between the conflict parties which is a core element of the [law of armed conflict], and endeavors to transform it into a unilateral shield for one side." 30

As Glazier explains, the law of war does not make killing combatants a war crime, unless it is done in particularly egregious ways. ${ }^{31}$ An unprivileged belligerent may be tried for murder if he kills a combatant, or attempted murder for trying to do so, but only as a domestic law matter, in a civilian court - not as a war crime in a military commission. Glazier quotes law of war expert Yoram Dinstein, who writes in his treatise on the law of armed conflict: "With unlawful combatants, [the law of armed conflict]refrains from stigmatizing the acts as criminal. It merely takes off a mantle of immunity from the defendant, who is therefore accessible to penal charges for any offense committed against the domestic legal system." 32 The International Committee of the Red Cross takes the same view. ${ }^{33}$

The United States' attempt to stretch the concept of "war crimes" in these ways is particularly telling in light of the fact that Al Qaeda fighters' status as unprivileged belligerents means that they have no "privilege of belligerency" and are therefore subject to ordinary domestic prosecution. It suggests a strong incentive to try detainees in military commissions. And that incentive, it seems, cannot be explained by any of the rationales President Obama has set forth. Even if military commissions were especially appropriate for the trial of war crimes, as opposed to courts-martial, the fact that many of the crimes defined by Congress and charged by the executive are not in fact legitimate war crimes directly undermines that rationale. It appears that the real motive for 
employing military commissions is a sense that convictions will be easier to obtain - and that is hardly a legitimate justification for affording second-class justice. That motive, in turn, may be driven by the preventive rationale; one way to make the law more effectively "preventive" is to reduce or eliminate safeguards for criminal defendants while expanding the scope of conduct subject to criminal prosecution. The military commissions do just that.

\section{CONCLUSION: TRANSPARENCY, ACCOUNTABILITY, AND FAIR PROCESS}

Even the physical design of the Guantánamo courtroom where military commission trials are conducted is shaped by the desire to conceal the government's own abuses. A soundproof glass wall separates the onlookers from the trial participants, so that the only way an observer can hear what is going on is through headphones with a forty second delay. The reason, according to Denny LeBoeuf, an ACLU lawyer advising on the defense of several detainees, is "the Rule: detainees are forbidden from speaking about their torture." Even in pretrial proceedings, the wall has been employed to block public transmission of information the military wants to keep secret - and the central secrets they seek to preserve are the details of the defendant's mistreatment and torture at U.S. hands. Remarkably, the US government has declared "classified" anything that the detainees say about their torture, and has required the lawyers, as a condition of access to their clients, to keep secret all details of their clients' treatment. But of course, the US cannot compel the detainees themselves not to speak of the unspeakable. The only way it can keep them from telling their stories is by keeping them detained, behind bars, behind glass, silenced.

That soundproof wall is an apt symbol for the United States' choice to use military commissions at all. It was and remains driven not by necessity, as war crimes may be tried in courts-martial, and most acts of terrorism that target or affect the United States or its citizens are crimes prosecutable in civilian criminal court. Rather, the choice to employ military commissions is driven by a sense that in some cases, we want to hold individuals responsible even where we lack admissible evidence establishing their guilt. The military commissions originally permitted reliance on statements obtained by torture. Today, tortured testimony is excluded, but the commission procedures still fall short of those provided in courts-martial. If they didn't, there would be no need for them, as they would be entirely duplicative. But the government has yet to offer any legitimate rationale for seeking an easier avenue to convictions. None of the justifications President Obama advanced withstand scrutiny. One is left feeling that the commissions are, in the end, nothing more than a way to get around the deal John Ashcroft advocated, and the Bush administration accepted, on September 12, 2001: "if we can't bring them to trial, so be it." That deal no longer looks so good, and the military commissions are an attempt to bring them to trial notwithstanding our own violations of law.

That strategy, however, is not sustainable. Any convictions obtained through military commissions are exceedingly likely to be viewed as illegitimate by much of the world. As such, they are likely to play into Al Qaeda's hands, much as our interrogation 
tactics at Abu Ghraib, the CIA black sites, and Guantánamo itself offered Al Qaeda the best propaganda it could find. Military commission convictions will support the terrorists' narrative, in which they are martyrs for a cause, fighting injustice - not brutal criminals who targeted innocent and defenseless civilians.

The fact that the United States employed a paradigm of prevention, and in some instances violated basic principles of international and domestic law in doing so, does not mean that terrorists must go free. The fact that a suspect has been tortured does not excuse his crimes, nor does it bar any prosecution. Torture taints subsequent evidence, but if the government can meet its burden of demonstrating that all of its evidence has an independent source, it may proceed with its trial. Much like the prosecution of a tortured defendant, the United States' efforts at bringing terrorists at Guantánamo to justice through the military system are tainted, not only by torture and mistreatment of defendants, but more broadly by the history of the military commissions themselves. This does not mean that alleged terrorists cannot be brought to justice. But it does mean that the United States bears a heavy burden of proving to the world that it has not profited from its illegal actions, and that it has cleared up the taint of the past. That burden is unlikely to be met in a military commission process that provides second-class justice only to foreign nationals. The best way forward would be to abandon the military commissions, and to commit to a principle of equality, in which foreign nationals accused of terrorism have the same rights as U.S. citizens accused of terrorism, whether in a civilian criminal court or a military court-martial.

\footnotetext{
${ }^{1}$ For a discussion of the many of the flaws of the American criminal justice system, in particular as it disparately affects racial minorities and the poor, see DAVID COLE, NO EQUAL JUSTICE: RACE AND CLASS IN THE AMERICAN CRIMINAL JUSTICE SYSTEM (1999).

${ }^{2}$ Hamdan v. Rumsfeld, 548 U.S. 557 (2006).

${ }^{3}$ See Ben Wizner, Op-Ed, Tribunals of the Absurd, L.A. TimES, Apr. 5, 2007, http://articles.latimes.com/2007/apr/05/opinion/oe-wizner5. ("In an ordinary justice system, the accused must be acquitted to be release. In Guantánamo, the accused must plead guilty to be released - because even if he is acquitted, he remains an 'enemy combatant' subject to indefinite detention. Only by striking a deal does a detainee stand a chance of getting out.").

${ }^{4}$ President Barack Obama, Remarks by the President on National Security (May 21, 2009) (transcript available at http://www.whitehouse.gov/the_press_office/Remarks-by-the-President-On-National-Security$5-21-09 /)$.

${ }^{5} I d$.

${ }^{6}$ See David Glazier, Still a Bad Idea: Military Commissions Under the Obama Administration 9-11 (Loyola-LA Legal Studies Paper No. 2010-32).

${ }^{7}$ Id. at $11-16$.

${ }^{8}$ Ex Parte Milligan, 71 U.S. (2 Wall.)

${ }^{9}$ Id. at 16 .
} 
${ }^{10}$ Louis Fisher, Military Commissions: Problems of Authority and Practice, 24 B. U. INT'L L. J. 15, 34-39 (2006).

${ }^{11} 18$ U.S.C. § $2441(2006)$.

1218 U.S.C. $\S \S 2339$ A, 2339B, 2339C (2006).

${ }^{13} 50$ U.S.C. $\S 1801(2007)$.

${ }^{14} 18$ U.S.C. app. $\S \S 1-16(2011)$.

${ }^{15}$ United States v. Tiede, 86 F.R.D. 227 (1979).

${ }^{16}$ A (FC) and Others v. Secretary of State for the Home Department, [2004] UKHL 56.

${ }^{17}$ See, e.g., United States v. Padilla, 508 U.S. 77 (1993); United States v. Lindh, 212 F.Supp. 2d 541 (E.D.Va. 2002); United States v. Ghailani, S10 98 Crim. 1023, NYLJ 1202472980095, at*1 (S.D.N.Y. Oct. 5, 2010).

${ }^{18}$ BOB WOODWARD, BUSH AT WAR 42 (2002) (emphasis added).

${ }^{19}$ See David Cole, Enemy Aliens: Double Standards and Constitutional Freedoms in the War

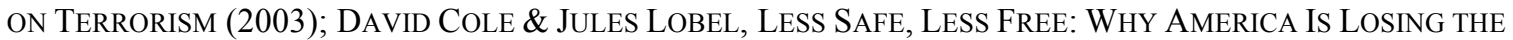
WAR ON TERRORISM (2007).

${ }^{20}$ Charlie Savage, William Glaberson, \& Andrew Lehren, Classified Files Offer New Insight Into Detainees, N.Y. TimeS, Apr. 24, 2011, at A1; Scott Shane \& Benjamin Weiser, Judging Detainees' Risk, Often with Flawed Evidence, N.Y. TIMES, Apr. 24, 2011, http://www.nytimes.com/2011/04/25/world/guantanamo-files-flawed-evidence-for-assessingrisk.html?_r=1\&pagewanted=all.

${ }^{21}$ See Dan Froomkin, Torture May Have Slowed Hunt for Osama, Not Hastened It, HuFFInGTON Post (May 6, 2011, 4:48 PM), http://www.huffingtonpost.com/2011/05/06/torture-may-have-slowedh_n_858642.html; Andrew Sullivan, The Big Lie, Ctd., The DaiLy BeAST (May 4, 2011, 11:29 AM), http://andrewsullivan.thedailybeast.com/2011/05/the-big-lie-.html.

${ }^{23}$ Military Commissions Act of 2006, 10 U.S.C. $\S \S 948(a)-(d)(2006)$.

${ }^{24}$ Military Commissions Act of 2009, 10 U.S.C. § 948r(a) (2009).

${ }^{25}$ Rogers v. Richmond, 365 U.S. 534 (1961); Ashcraft v. Tennessee, 322 U.S. 143 (1944).

${ }^{26} 10$ U.S.C. $\S 948 \mathrm{r}(\mathrm{c})(2)(\mathrm{A})$.

${ }^{27} 10$ U.S.C. $\S 950 t(25)(A)$.

${ }^{28}$ Hamdan v. Rumsfeld, 548 U.S. 557 (2006).

${ }^{29}$ Glazier, supra note 6, at 65-86; see also David Glazier, A Court Without Jurisdiction: A Critical Assessment of the Military Commission Charges Against Omar Khadr (Loyola-LA Legal Studies Paper No. 2010-37).

${ }^{30}$ Glazier, supra note 6, at 77. 
${ }^{31}$ It is a war crime, for example, to use a prohibited weapon, such as poison, or to kill by means of treachery or perfidy. Glazier, supra note 6, at 70-71.

${ }^{32}$ Glazier, supra note 6, at 72 (quoting Yoram Dinstein, THE CONDUCt OF Hostilities Under THE LAW OF INTERNATIONAL ARMED CONFLICT 200 (2004)).

${ }^{33}$ Glazier, supra note 6, at 72-73 (quoting INTERNATIONAL COMMITTEE OF THE RED CROSS, INTERPRETIVE GUIDANCE ON THE NOTION OF DiRECT PARTICIPATION IN HOSTILITIES UNDER INTERNATIONAL

HUMANITARIAN LAW 83-84 (2009)). 